\title{
A operação de Sofield e Millar no tratamento da Osteogênese Imperfeita
}

\author{
Sofield and Millar technique in the treatment of osteogenesis imperfecta
}

Cláudio Santili', Miguel AkKarl $I^{2}$, Gillberto Waisberg ${ }^{3}$, André Luis Lugnani de Andrade", UnGarI DA COSTA4, ANDRÉ LUIZ MACHADO SILVAa

SÉRGIO EDUARDO

\section{RESUMO}

A osteogênese imperfeita é uma doença genética causada por um defeito do colágeno do tipo I. Os portadores caracterizam-se pela baixa estatura, escleras azuladas, deformidades esqueléticas e fragilidade óssea. Os autores analisam os resultados da operação de Sofield e Millar que foi realizada em 23 ossos acometidos em oito portadores de osteogênese imperfeita com deformidades e antecedentes de múltiplas fraturas. Após um seguimento médio de dez anos e dois meses, onze ossos não precisaram ser reoperados; doze ossos, no entanto, apresentaram 21 complicações pós-cirúrgicas sendo: dez migrações das hastes intra-medulares, seis refraturas, três recidivas da deformidade e duas pseudartroses. Não houve caso de infecção ou lesão neurovascular. A reoperação, quando necessária, ocorreu após um tempo médio de três anos e seis meses. Todos os pacientes melhoraram ou mantiveram a capacidade de deambulação logo após a cirurgia; porém, com o tempo, dois deles, portadores de formas mais graves da doença, deterioraram sua capacidade de deambulação tornando-se não deambuladores. Os autores concluem que a operação torna possível a correção das deformidades e previne temporariamente a sua recidiva, além de tornar as fraturas menos freqüentes. No entanto, devido ao crescimento esquelético e a indistensibilidade das hastes intramedulares utilizadas, as complicações ocorrem.

Descritores: Osteogênese imperfeita; Marcha; Osteotomia

\section{SUMMARY}

Osteogenesis imperfecta is a genetic disease caused by defects in the synthesis of type I collagen; clinical characteristics are short stature, blue or gray sclera, skeletal deformities and bone fragility. We analyzed eight cases of osteogenesis imperfecta with deformities and history of many fractures, for that the Sofield and Millar surgery was performed in 23 bones. After a mean follow up period of ten years and two months, 11 bones did not need revision, twelve bones had 21 complication that needed revision, ten by rod migration, six by refracture, three by new deformities and two by nonunion. There were no cases of infection or neurovascular lesion. This surgery was able to correct deformities, make fracture less frequent and prevent new deformities; revisions were necessary three years and two months after the primary surgery. All patients maintained or improved their ability to walk right after surgery; during the follow up, two patients, in which the disease was more severe, had their walking ability decreased and are non ambulatory now.

Keywords: Osteogenesis imperfecta; gait; osteotomy
Trabalho realizado no Grupo de Ortopedia Pediátrica do Departamento de Ortopedia e Traumatologia da Santa Casa de Misericórdia de São Paulo, Pavilhão "Fernandinho Simonsen" (DOT-SCMSP)

1. Chefe Adjunto de Clínica e do Departamento e do Grupo de Ortopedia Pediátrica da Faculdade de Ciências Médicas da Santa Casa de São Paulo.

2. Médico Assistente do Grupo de Ortopedia e Traumatologia Pediátrica e Mestre em Ortopedia e Traumatologia pela Faculdade de Ciências Médicas da Santa Casa de São Paulo.

3. Médico Assistente do Grupo de Ortopedia e Traumatologia Pediátrica e Pós Graduando em Ortopedia e Traumatologia pela Faculdade de Ciências Médicas da Santa Casa de São Paulo.

4. Membro Titular as SBOT e ex-residente do Departamento de Ortopedia e Traumatologia da Santa Casa de São Paulo

Endereço para correspondência: Departamento de Ortopedia e Traumatologia da Santa Casa de São Paulo - Grupo de Ortopedia Pediátrica do Hospital e da Faculdade de Ciências Médicas da Santa Casa de São Paulo

Rua Cesário Motta Jr. 112, Vila Buarque - CEP: 01277-900 - São Paulo - SP.

Email: c.santili@terra.com.br

Trabalho recebido em 13/02/2004. Aprovado em 16/07/2004
Study carried out in the Pediatric Orthopedics Group of the Department of Orthopedics and Traumatology of Santa Casa de Misericórdia de São Paulo, "Fernandinho Simonsen" Building (DOT-SCMSP)

1. Adjunct Chief of Clinics and Department and of the Pediatric Orthopedics Group of the Medical Sciences School of Santa Casa de São Paulo.

2. Assistant Physician of the Pediatric Traumatology and Orthopedics Group and Master Degree in Orthopedics and Traumatology conferred by the Medical Sciences School of Santa Casa de São Paulo.

3. Assistant Physician of the Pediatric Traumatology and Orthopedics Group and Postgraduate Student in Orthopedics and Traumatology at the Medical Sciences School of Santa Casa de São Paulo.

4. Titular Member of Brazilian Society of Orthopedics and Traumatology and exresident at the Department of Orthopedics and Traumatology of Santa Casa de São Paulo

Address: Department of Orthopedics and Traumatology of Santa Casa de São Paulo - Pediatric Orthopedics Group do Hospital and Medical Sciences School of Santa Casa de São Paulo

Rua Cesário Motta Jr. 112, Vila Buarque - São Paulo - SP. CEP: 01277-900

Email: c.santili@terra.com.br 


\section{INTRODUÇÃO}

A osteogênese imperfeita $(\mathrm{Ol})$ é uma doença genética causada por um defeito qualitativo e quantitativo na síntese do colágeno do tipo I. Incide em aproximadamente 1:20000 nascimentos, não havendo prevalência racial ou étnica ${ }^{(17,18)}$

O quadro clínico é de grande variabilidade, sendo que os indivíduos acometidos, de forma geral, apresentam baixa estatura, osteopenia, múltiplas fraturas e deformidades ósseas progressivas. Características adicionais são: escleras azuis ou acinzentadas, dentinogênese imperfeita, frouxidão ligamentar e surdez precoce ${ }^{(5)}$

Até os dias de hoje, não há tratamento clínico específico para corrigir o defeito básico da osteogênese imperfeita ${ }^{(12,22)}$, sendo que o tratamento ortopédico atem-se a tratar e prevenir fraturas, corrigir deformidades e evitar sua recorrência, permitindo a ortetização e, muitas vezes, propiciando a deambulação ${ }^{(3,12,16)}$.

Quando as fraturas são tratadas de maneira incruenta, com imobilização do membro afetado, a falta de movimento agrega maior osteoporose ao osso(2). Assim, a imobilização deve ser usada o mínimo de tempo possível, a fim de evitar o aumento da osteopenia e o maior risco de fraturas ${ }^{(21)}$, principalmente dos ossos longos que vão sofrendo deformação pela tensão muscular mediante crescimento ósseo. (Fig. 1)

Em 1959, Sofield e Millar ${ }^{(19)}$ revolucionaram o tratamento das deformidades e das fraturas dos ossos longos na Ol, realizando múltiplas osteotomias no segmento deformado, permitindo o realinhamento dos fragmentos e sua estabilização com haste intramedular, o que melhorou significativamente o prognóstico dos pacientes ${ }^{(19)}$

O objetivo deste estudo é avaliar os resultados cirúrgicos obtidos nos pacientes portadores de Ol submetidos à operação de Sofield e Millar ${ }^{(19)}$, com ênfase na sua influência na capacidade de deambulação, nas complicações e necessidade de reoperações.

\section{MATERIAL E MÉTODOS}

No período de 1972 e 1995 no Departamento de Ortopedia e Traumatologia da Santa Casa de São Paulo, foram operados 33 pacientes portadores de OI, dos quais 10 haviam sido submetidos à operação de Sofield e Millar ${ }^{(19)}$

Estes pacientes foram convocados, por meio de carta ou

\section{INTRODUCTION}

Osteogenesis imperfecta $(\mathrm{O} /)$ is a genetic disease caused by a qualitative and quantitative defect in the synthesis of type-1 collagen. The incidence of $\mathrm{OI}$ is approximately 1:20,000. births with no predilection for any particular race or ethnic group ${ }^{(17,18)}$.

Clinical characteristics greatly vary, generally including short stature, osteopenia, multiple fractures, and progressive bone deformities. Additional features are blue or gray sclera, dentinogenesis imperfecta, laxity of ligaments, and early deafness ${ }^{(5)}$.

No specific clinical treatment is available at present that can correct the basic defect found in O/(12,22). Orthopedic treatment aims to treat and prevent fractures, correct deformities, and avoid their recurrence. As a result, orthoses can be used and walking is thus made possible in many cases $(3,12,16)$.

When fractures are treated with immobilization of the affected limb, immobility increases osteoporosis ${ }^{(2)}$. Therefore, immobilization must be used for minimal periods so as to avoid increases in osteopenia and risk for fracture(21) mainly of long bones that are subject to deformation due to muscular tension as a result of bone growth (Figure 1).

In 1959 Sofield e Millar revolutionized the treatment for deformities and fractures of long bones in $\mathrm{Ol}$ patients, performing several osteotomies in deformed segments. This allowed one to realign fragments and stabilize them with the help of an intramedullary rod. With this technique, prognosis significantly improved (9).

The present study aims to evaluate surgical results obtained in patients with Ol submitted to Sofield and Millar operation ${ }^{(19)}$, emphasizing the effects upon walking hability, complications, and need for repeated operations.

\section{MATERIAL AND}

\section{METHODS}

From 1972 to 1995, 33 patients with OI were operated at the Department of Orthopedics and Traumatology of the Santa Casa de São Paulo; Sofield and Millar ${ }^{(19)}$ operation was carried out in 10 out 33 cases

These patients were requested, by phone or by mail, to return to hospital for reavaluation. Two of them did not return to hospital: one patient moved and the other patient had morbid obesity and was not able to return to hospital.

Patients who returned to hospital or their legal representatives were informed of their participation in the research study and gave their informed consent.

Patients were interviewed and the preoperative, postoperative, and current gait pattern was classified according to Hoffer and Bullock criteria(7) (Table 1). In addition, patients were clini- 
telefonema, a comparecer ao hospital para reavaliação. Dois deles não atenderam ao chamado, sendo que um não foi encontrado por mudança de domicílio e outro apresentava obesidade mórbida, sendo difícil sua locomoção ao hospital.

Os pacientes que compareceram ou seus responsáveis foram informados sobre sua participação no trabalho e consentiram com seus termos.

Os pacientes foram entrevistados com o objetivo de definir o padrão de marcha pré-operatório, pós-opertatório e atual, sendo classificados de acordo com os critérios de Hoffer e Bullock $^{(7)}$ (Tabela 1). Foram também avaliados clínica e radiograficamente e classificados segundo os critérios de Sillence et al. ${ }^{(17)}$ quanto ao tipo de OI (Tabela 2).

Os prontuários e as radiografias foram revisados quanto ao histórico das fraturas, deformidades e tratamentos prévios, idade na operação e a técnica cirúrgica realizada. Foram analisadas as complicações, os motivos pelos quais ocorreram e o tempo pós-operatório em que aconteceram.

Todos os oito pacientes apresentavam inicialmente deformidades e antecedentes de múltiplas fraturas conseqüentes a traumas de baixa energia. Seis eram do sexo masculino e dois do sexo feminino. Segundo a classificação de Sillence et al.(17), quatro pacientes eram do tipo I , um paciente era do tipo III e três eram do tipo IV.

Nestes pacientes a operação de Sofield e Millar ${ }^{(17)}$ foi realizada após ampla exposição subperiosteal de toda a diáfise, sendo então realizadas as osteotomias necessárias, porém no menor número possível para permitir o realinhamento ósseo numa seqüência alternada de concavidades e convexidades e subseqüente fixação intramedular com haste. Todas as hastes eram não extensíveis (Fig. 2 e 3 ).

Foram operados 14 fêmures, cinco tibias, dois rádios e duas ulnas, totalizando 23 ossos. A média de idade dos pacientes nos 23 procedimentos foi de dez

cally and radiographically evaluated as for the type of Ol according to Sillence et al. criteria(17) (Table 2).

Patients' records and radiographs were reviewed as for history of fractures, deformities, and previous treatments, age at the time of surgery, and surgical technique. Complications, reasons for complications, and time interval from surgery until complications developed were analyzed.

Initially, all the eight patients showed deformities and antecedents of multiple fractures due to low energy traumas

Six were male and two were

Classificação do padrão de marcha segundo Hoffer e Bullock ${ }^{(7)}$ Classification of walking pattern according to Hoffer and Bullock ${ }^{111}$ TIPO Tipo de Marcha

Type Walking Type

I Deambulador comunitário/ Community walking

II Deambulador domiciliar / Home walking

III Marcha funcional / Functional walking

IV Restrito a cadeira de rodas (transferidor independente) Confinement to wheelchair (transferrer-independent) $\checkmark \quad$ Restrito a cadeira de rodas (transferidor dependente) Confinement to wheelchair (transferrer-dependent) VI Deitador / Lying

Tabela 1 - Classificação do padrão de marcha Table 1 - Classification of walking pattern according

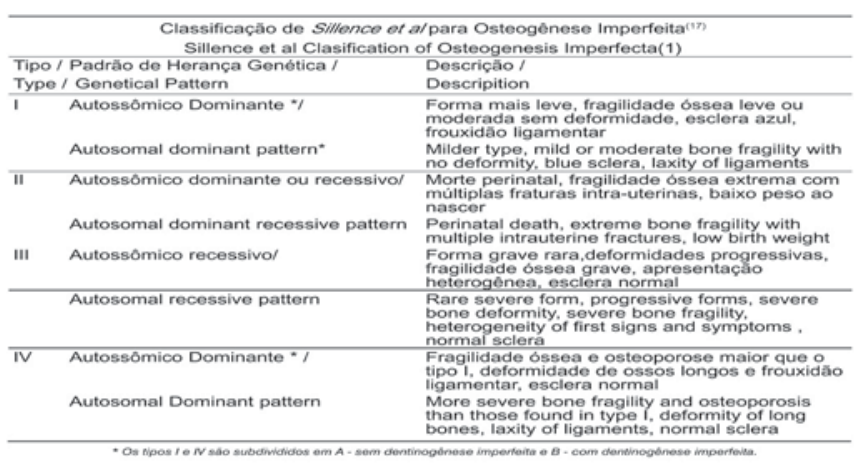

Tabela 2 - Classificação para Osteogênese imperfeita Table 2 - Classification of Osteogênesis imperfect

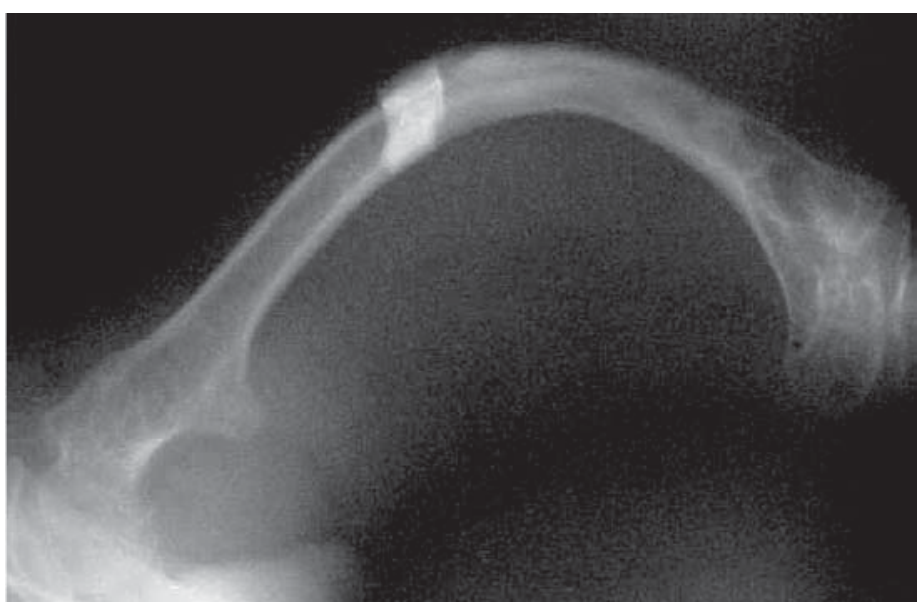

Figura 2 - Radiografia pré-operatória do fêmur no perfil mostrando

Figure 2 - Preoperative lateral radiograph of femur showing a fracture and bone deformity. female. According to Sillence et al's classification (17)

Four patients were type I, one patient was type III and three were type $\mathrm{N}$.

The Sofield and Millan's operation was performed in these patients after a huge

subperiosteal exposition of the whole diaphysis

And then the necessary osteotomies were performed in order only to permit the osseous realignment

In an alternated sequence of concavities and convexities followed by an intramedullary fixation with a shaft.

All the shafts were not extensible

Fourteen femurs, five tibias, two radius and two ulnas were operated, in a total of 23 bones.

The average age of the patients of the 23 procedures was 10 years and two months, varying from two years and two months to twenty three years.

The average post-operative period was 12 years and 6 months, varying from two months to 35 years.

From 23 operated bones, 12 needed new surgeries in a total of 21 new surgeries

Tem migrations of shafts occurred, and the shafts were removed from four of them

as the osteotomies were consolidated. Four were submitted to new surgeries using the Sofield and Miller's technique (19), as the deformity reappeared and two shafts were repositioned.

Six bones presented new fractures and from these two were submitted to reduction and change of

Intramedullary shaft by a larger and with a larger diameter one and four underwent

new surgery of Sofield and Millar (19) because there was 
anos e dois meses, variando de dois anos e dois meses a 23 anos. O seguimento pós-operatório médio foi de 12 anos e seis meses, variando de dois meses a 35 anos.

Dos 23 ossos operados, 12 necessitaram novas cirurgias totalizando 21 reoperações. Ocorreram 10 migrações de haste, sendo em quatro realizada a retirada da mesma, pois as osteotomias estavam consolidadas. Quatro foram submetidos à reoperação pela técnica de Sofield e Millar ${ }^{(19)}$, uma vez que houve recidiva da deformidade e duas hastes foram reposicionadas. Seis ossos apresentaram refraturas e destes, dois foram submetidos à redução e troca haste intramedular por outra de tamanho e diâmetro maiores e quatro sofreram nova operação de Sofield e Mi$\|{ }^{(19)}$ pois havia deformidade associada. Observamos em outros três ossos a recidiva da deformidade sendo realizada uma nova operação de Sofield e Millar(19) (Fig - 4). A média geral de tempo entre a primeira operação e a revisão da operação de Sofield e Millar ${ }^{(19)}$ foi de 3 anos e 6 meses.

Ocorreram duas pseudartroses em um único paciente, que teve o fêmur esquerdo operado aos 15 anos e dois meses e a tíbia esquerda operada aos 17 anos. As duas falhas de consolidação evoluíram satisfatoriamente após a troca da síntese e colocação de enxerto ósseo. Nenhum paciente apresentou infecção ou lesão neurovascular (Tabela 3).

\section{RESULTADOS}

De acordo com a classificação de Hoffer e Bullock ${ }^{(7)}$ para a marcha, antes da cirurgia dois pacientes eram deambuladores comunitários (tipo I), quatro pacientes eram deambuladores domiciliares (tipo II), um paciente era deambulador funcional (tipo III) e um paciente era restrito à cadeira de rodas sendo transferidor dependente (tipo V). Por um período de tempo após a cirurgia, três pacientes apresentaram melhora na capacida-

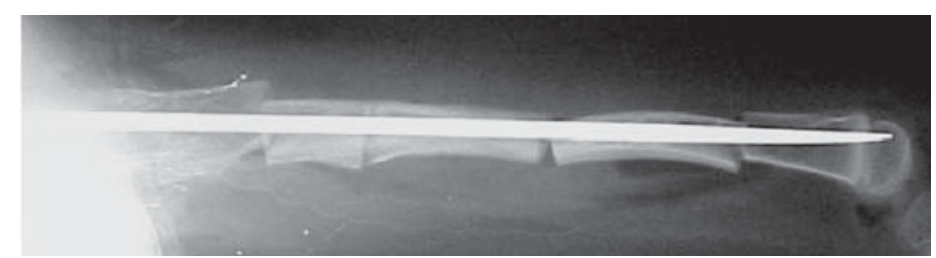

Figura 3-Radiografia pós-operatória do fêmurno perfil mostrando as múltiplas osteotomias, o realinhamento dos fragmentos e a fixação intramedular

Figure 3 - Postoperative lateral radiograph of femur showing multiple osteotomies, fragment realignment, and intramedullary fixation.

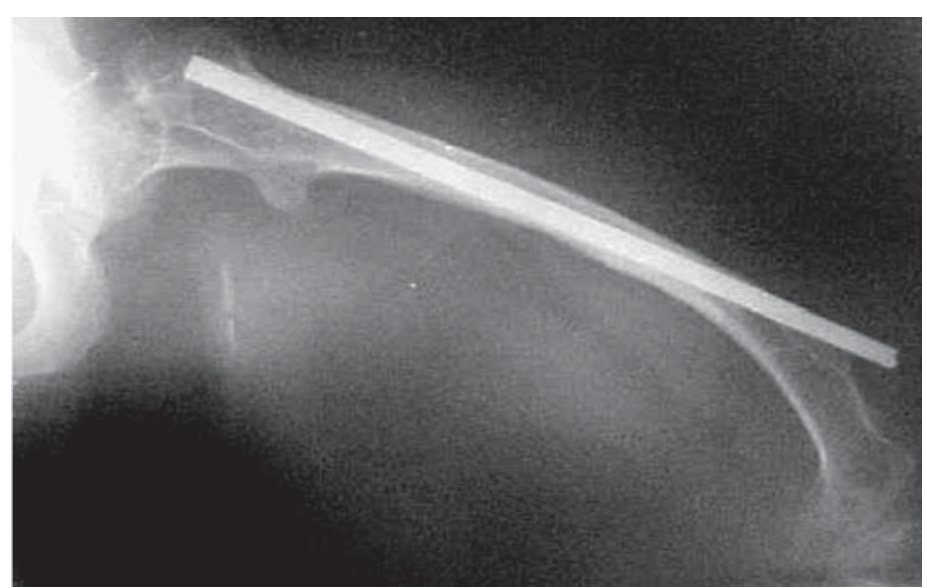

Figura 4 - Radiografia do fêmur no perfil mostrando recidiva da deformidade com a haste protruindo externamente ao osso

Figure 4 - Lateral radiograph of femur showing deformity recurrence with rod protrusion outside the bone

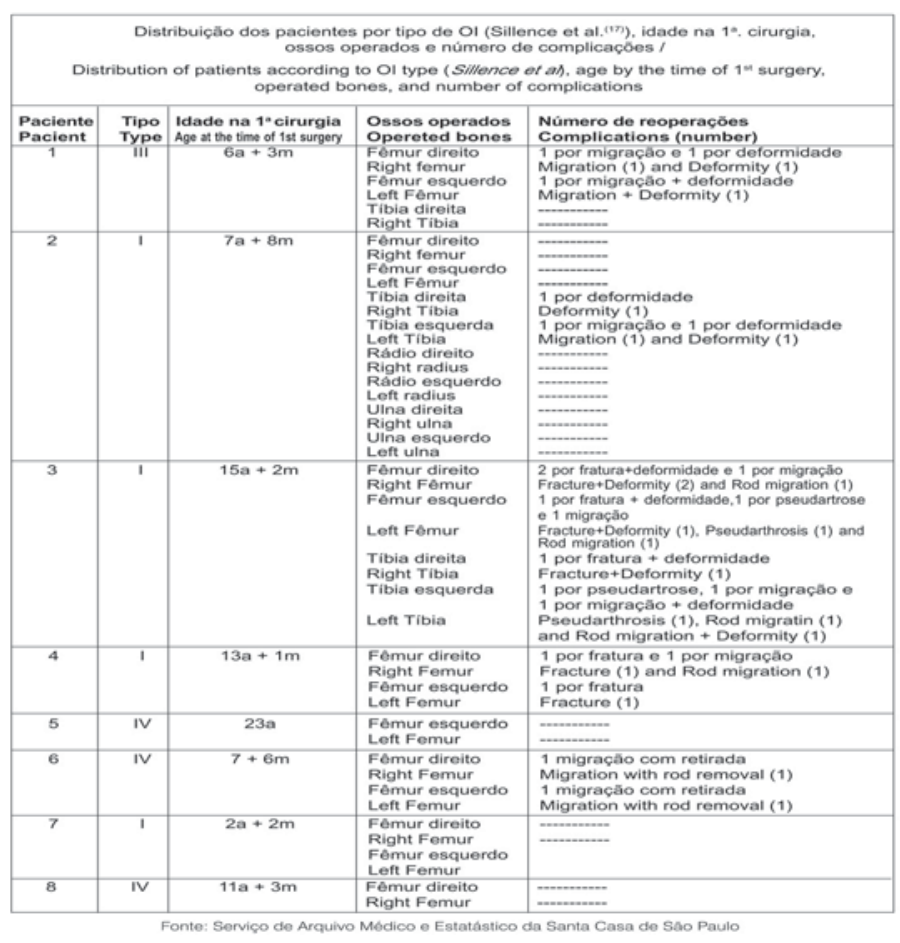

Tabela 3 - Distribuição de paciemtes por tipo de OI Distribuition of Table 3 - patients according OIType an associated deformity.

We observed the reappearance of the deformity in other three bones and a new surgery of Sofield and Millar (19) was performed (Fig 14).

The general average time between the first surgery and the review of the surgery of Sofield and Millar (19) was 3 years and 6 months.

Two pseudoartrosis occurred in a single patient who had his left femur operated when he was 15 years and 2 months old and the left tibia operated when he was 17 years old.

The two failures of consolidation developed successfully after the change of the synthesis and the placing of the osseous graft. None of the patients presented infection or neurovascular injury. (Table 3)

\section{RESULTS}

Six male and two female patients had deformities and history of multiple fractures due to lowenergy traumas at the beginning of treatment. According to the classification described by Sillence et $\mathrm{al}^{(1)}$, four were of type I, one was of type III, and three were of type $\mathrm{N}$.

Sofield e Millar ${ }^{(10)}$ was performed in all cases following extensive subperiosteal exposure of the whole diaphysis. The smallest number of osteotomies were carried out so as to allow bone realignment, alternating concavities and convexities, and subsequent intramedullary rod fixation. Rods were not of the extensible type (Figures 2 and 3).

Fourteen femora, 5 tibiae, 2 radii, and 2 ulnae were operated, with a total of 23 bones. The mean age of patients was 10 years and 2 months for the 23 operations, raging from 2 years and 2 mon- 
de de deambulação passando dos tipos II, III e V para I, II e I respectivamente; cinco pacientes mantiveram a mesma capacidade de deambulação prévia à cirurgia. Atualmente dois pacientes estão restritos à cadeira de rodas sendo transferidores independentes (tipo IV), dois são deambuladores domiciliares (tipo II) e quatro são deambuladores comunitários do tipo I (Tabela 4). ths to 23 years. Postoperative follow-up averaged 12 years and 6 months, ranging from two months to 35 years.

Twelve out of a total of 23 bones required revision, with a total of 21 operations. Rod migration was seen in 10 cases. In four cases, rod was removed since osteotomies were consolidated. In four cases Sofield and Millar(10) technique was employed since deformity had reappeared and two rods were repositioned.

Refractures were seen in six bones, two of them were submitted to reduction and intramedullary rods were replaced by other of greater size and diameter, and Sofield and Millar ${ }^{(10)}$ technique was used in four cases since there was an associated deformity. Deformity recurred in three bones and Sofield and Millar ${ }^{(10)}$ technique was used (Figure 4). The mean time period between the first operation and revision by the Sofield e Millar ${ }^{(10)}$ technique was 3 years and 6 Tabela 4 - Distribuição dos pacientes segundo o padrão de marcha
pré-operatório, pós operatório e atual Table 4 - Distribuition of patients according to preoperative, postoperative
and current walking pattern deria levar células mesenquimais com capacidade de se diferenciar em osteoblastos, os quais passariam a produzir colágeno normal, aumentando a resistência e a qualidade do osso, no entanto, estudos preliminares neste sentido ainda estão em andamento e apresentam resultados controversos ${ }^{(8)}$. Os bisfosfonatos por sua vez, parecem ser a única classe de medicamentos com algum efeito terapêutico, pois ao inibir a reabsorção óssea, reduzem a osteoporose e propiciam menores perdas da massa óssea ${ }^{(6)}$.

Quando ocorre fratura, o tratamento incruento resulta em consolidação óssea na maioria dos casos, contudo o paciente é submetido obrigatoriamente a longos períodos de imobilização. Esta impossibilidade de movimentos leva a uma maior osteoporose, a qual se soma ao defeito básico do colágeno, fragilizando ainda mais o osso(2), que passa a se encurvar mediante as ações das forças gravitacional e muscular, que agem aumentando a deformidade ${ }^{(2,10,21)}$. Como a maioria das fraturas nesses ossos longos ocorre no ápice da deformidade, cria-se um ciclo vicioso (Fig. 1).

O tratamento cirúrgico proposto por Sofield e Millar ${ }^{(19)}$, que preconiza múltiplas osteotomias do segmento deformado, realinhamento dos fragmentos e sua fixação com haste intramedular, permite corrigir as deformidades e diminui o tempo de imobilização, eliminando dois fatores importantes deste ciclo vicioso, além de dar um suporte de maior resistência ao osso, devido à presença da haste intramedular ${ }^{(12,22)}$.

Nos 23 ossos operados e analisados apenas seis refraturaram, e nestes isto ocorreu em média, quatro anos e sete meses após a cirurgia, confirmando uma certa eficácia do método na prevenção de repetidas fraturas ${ }^{(10,12,16,21,22)}$. A migração da haste no período pós-operatório ocorreu em dez situações, e embora seja uma das complicações mais freqüentes, é de fácil resolução mediante o reposicionamento ou da retirada da haste(22). Em quatro oportunidades ocorreu a deformidade progressiva da extremidade após a migração proximal da haste, sendo necessária a reoperação segundo a técnica de Sofield e Millar ${ }^{(19)}$. A migração da haste se explica pelo fato desta se ancorar meIhor nos segmentos ístmicos da diáfise, os quais são muitas vezes desperiostizados para a frezagem e alargamento do canal. Estes fragmentos desvitalizados são reabsorvidos para sua reintegração e assim, a haste pode tornar-se totalmente solta dentro do canal medular por perder apoio nas paredes internas das

months. Pseudarthrosis was seen in two bones from one patient: left femur operated when the patient was aged 15 years and 2 months; and the left tibia operated when the patient was 17 years old. In both cases lack of consolidation resolved following bone graft and synthesis replacement. Infections or neurovascular complications did not occur in any patient (Table 3).

According to Hoffer e Bullock ${ }^{(11)}$ classification of walking hability before surgery, the following was observed: community walking (type I) in 2 patients; home walking (type II) in 4 patients; functional walking (type III) in 1 patient; and confinement to wheelchair and transferrer-dependent (type V) in 1 patient. Improvement in walking hability for some time following surgery was seen in three patients, specifically from type II, III, and V to I, II, and I, respectively. Walking hability remained unaltered in five patients despite surgery. The current classification is the following: confinement to wheelchair and transferrer-independent (type IV): 2 patients; home walking (type II): 2 patients; and community walking (type I): 4 patients (Table 4).

\section{DISCUSSION}

Osteogenesis imperfecta is associated with progressive deformity and fractures that are difficult to treat due to bone fragility and osteoporosis ${ }^{(4)}$

As for clinical possibilities of treatment for Ol, bone marrow transplant could theoretically transfer mesenchymal cells able to differentiate into osteoblasts, which would, in turn, produce normal collagen, thus increasing bone quality and resistance. However, preliminary studies are under way and have shown controversial results ${ }^{(12)}$. Biphosphonates, in turn, seem to be the only class of drugs with some therapeutic effect since they reduce osteoporosis, thus decreasing bone mass loss, by inhibiting bone resorption ${ }^{(13)}$.

When a fracture develops, noninvasive treatment results in bone consolidation in the majority of cases. However, long periods of immobilization are required. Immobilization aggravates osteoporosis. In conjunction with the basic defect of colagen, osteoporosis aggravates bone fragility ${ }^{(8)}$, and bones assume a curved shape due to the action of muscular and gravitational forces, responsible for deformity aggravation ${ }^{(8,9,14)}$. Since the majority of fractures in long bones affect the most prominent area of deformity, a vicious cycle develops (Figure 1).

The surgical technique described by Sofield and Millar ${ }^{(10)}$ in- 
corticais da diáfise e migra longitudinalmente na direção pela qual foi introduzida(22).

A recidiva da deformidade não associada à migração da haste foi observada em sete ossos. Na sua maioria, os pacientes são operados quando ainda muito jovens, e conseqüentemente, com o crescimento ósseo a haste torna-se pequena, permitindo que o segmento ósseo metafisário não protegido e não encavilhado se deforme e tenda a fraturar ou à extrusão da haste(Fig. 4), por isso, geralmente são necessárias revisões a cada dois anos ou dois anos e meio ${ }^{(1,12,13,19,22)}$.

Nos nossos pacientes essas revisões ocorreram após um tempo médio de três anos e seis meses, provavelmente pelo fato de que nesta amostragem os pacientes foram operados com uma média de idade maior (dez anos e dois meses) e, conseqüentemente, com menor potencial de crescimento residual.

A necessidade de múltiplas reoperações levou Bailey e Dubow, em 1963, ao desenvolvimento de hastes extensíveis, capazes de alongarem-se por telescopagem passiva, uma vez que são fixas nas extremidades do osso. Este dispositivo evita muitas vezes, evita a necessidade de revisão, pois acompanha o crescimento ósseo ${ }^{(1)}$.

Nos pacientes já na maturidade esquelética ou com expectativa de crescimento ósseo menor que três centímetros estão indicadas as hastes não extensíveis, pois o risco de recidiva da deformidade ou de fratura é menor ${ }^{(13)}$. Nos pacientes com expectativa de crescimento ósseo maior, estão indicadas as hastes extensíveis, embora não haja consenso sobre sua indicação pois, se por um lado retardam a necessidade de revisão, por outro aumentam a morbidade por prolongarem o tempo cirúrgico devido a dificuldade na sua execução e estão sujeitas a um número maior de complicações ${ }^{(1,11,20)}$.

Embora a cirurgia de Sofield e Millar ${ }^{(19)}$ pareça muito agressiva, não foi observada complicação neurovascular ou infecção. Tivemos apenas um paciente que evoluiu para a pseudartrose em dois de seus ossos operados. O mesmo já se encontrava na maturidade esquelética na época da cirurgia, sendo esta uma condição associada à maior incidência de retarde de consolidação e pseudartrose ${ }^{(20,22)}$. Estas duas pseudartroses evoluíram para a consolidação após a troca da síntese e colocação de enxerto ósseo.

O método foi aplicado nos ossos do membro superior em apenas quatro oportunidades, não sendo nestes casos necessária reoperação alguma. O baixo número de ossos operados nos membros superiores se deve à menor frequência das fraturas e à maior tolerabilidade quanto as deformidades ${ }^{(9)}$.

Os nossos pacientes foram operados com uma média de idade de 10 anos e 8 meses e esta é uma idade avançada em relação ao que se encontra na literatura, que varia de quatro a oito anos na média ${ }^{(12,16,19,20)}$. Dois dos nossos pacientes iniciaram o tratamento com idade mais avançada, desviando para cima a média de idade dos pacientes operados (23 e 15 anos). A melhor idade para a execução do procedimento cirúrgico seria quando o paciente inicia a marcha, auxiliando-o no seu desenvolvimento ${ }^{(22)}$, muito embora isto dependa sempre da gravidade da doença. Pacientes menores que três ou quatro anos com tipos mais graves de Ol podem ser submetidos à osteoclasia fechada e fixação intramedular percutânea, propiciando a correção das deformidades e estabilização óssea com um procedimento menos invasivo, sem comprometer futuros tratamentos $^{(14,15)}$. volves several osteotomies of the deformed segment and its fixation with intramedullary rod. It allows one to correct deformities and decreases immobilization time, thus eliminating two important factors of this vicious cycle. In addition the bone becomes more resistant due to the intramedullary rod ${ }^{(4,5)}$.

In our study sample (23 bones), refracture developed in six bones 4 years and 7 months, on average, following surgery, thus confirming the efficacy of the method in preventing repeated fractures ${ }^{(4-6,9,14)}$. Intramedullary rod migration following surgery occurred ten times. Although this is one of most frequent complications, it is easy to treat by repositioning or removal of intramedullary rod ${ }^{(5)}$. Progressive deformity of the limb occurred four times following proximal migration of the rod; surgery was performed by Sofield e Millar ${ }^{(10)}$ technique. Rod migration is explained by the fact that the rod is better anchored on the isthmic segments of diaphysis whose periosteum was removed by milling when the cavity was widened. These devitalized fragments are reabsorbed for reintegration while the intramedullary rod is fully released within the medullary cavity when its support on the inner wall of the diaphysis cortical layer is lost. As a result, the intramedullary rod longitudinally migrates towards its insertion point ${ }^{(5)}$.

Recurrence of deformity not associated with rod migration was seen in seven bones. In the majority of cases patients were operated when they were too young. Therefore, with bone growth, the rod has become relatively smaller, allowing the metaphysial bone segment that is not protected and supported to deform, with a tendency to fracture or rod extrusion (Figure 4). Revisions are, therefore, required at 2-2,5-year intervals approximately $(4,5,10,15,16)$.

In our patients surgical revisions were performed following 3 years and 6 months, on average, probably due to the fact that our sample included patients who had been operated when they were aged 10 years and 2 months, on average, and had, therefore, a smaller potential for residual growth.

The need for multiple surgeries led Bailey and Dubow to develop extensible rods in 1963. These rods are able to passively elongate since their extremities are not fixed on bones. With the use of this device, surgical revision is avoided in many cases, since extensible rods accompany bone growth ${ }^{(15)}$.

In patients with skeletal maturity or in whom a bone growth $\leq$ $3 \mathrm{~cm}$ is expected, nonextensible rods are indicated since the risk for deformity recurrence or fracture is lower ${ }^{(16)}$. In patients in whom bone growth is $>3 \mathrm{~cm}$, extensible rods are indicated although its indication is not a consensus. On the one hand, surgical revision is delayed, but, on the other hand, extensible rods are associated with increased morbidity because surgical duration is increased due to technical difficulty. In addition, a great number of complications are associated with this procedure $(15,17,18)$.

Neurovascular complications or infections were not seen although Sofield e Millar technique ${ }^{(10)}$ seems to be very aggressive. Only one patient developed pseudarthrosis in one of the two operated bones. This patient was already skeletally mature at the time of surgery. Skeletal maturity is associated with consolidation delay and pseudarthrosis ${ }^{(5,18)}$. In both cases lack of consolidation resolved following bone graft and synthesis replacement.

This technique was used in the arm in four cases only. Surgical revision was not required in these cases. The small number of upper-limb bones requiring surgery is due to lower frequency of fractures and greater tolerability as far as deformities are concerned(19)

Our patients were aged 10 years and 8 months, on average, at the time of surgery in contrast with the age of 4 to 8 years, on average, reported in literature ${ }^{4,6,10,18)}$. Two of our patients were older (23 and 15 years) at the time of surgery. Therefore, the mean age of study patients was increased. The best age for surgery 
De maneira geral a capacidade de deambulação nos pacientes portadores de Ol é determinada pela gravidade da doença, sendo prejudicada pelas deformidades e múltiplas fraturas que levam o paciente a longos períodos de imobilização(4,9)

Após a cirurgia, observamos que, nenhum paciente apresentou piora da capacidade de deambulação, havendo inclusive melhora do padrão de marcha em três pacientes, na decorrência direta dos benefícios da correção das deformidades e estabilização esquelética dos membros. Embora inicialmente nenhum paciente tenha apresentado piora da capacidade de deambulação, após algum tempo, dois pacientes classificados segundo os critérios de Sillence et al. ${ }^{(17)}$ em tipo III e tipo IV, tornaram-se mais tarde não deambuladores. Sabidamente, na sua evolução natural, os tipos III e IV apresentam grande fragilidade óssea e osteoporose acentuada, e perdem as habilidades motoras na segunda década de vida por evoluírem com deformidades na coluna, perda da motivação e tendem ao uso de cadeira de rodas ${ }^{(5,17)}$.

Embora a operação de Sofield e Millar ${ }^{(19)}$ possibilite a correção das deformidades e reduza a freqüência das fraturas, estas não são as únicas variáveis que interferem na capacidade de deambulação( ${ }^{(9)}$. A imobilização, a diminuição da força muscular e da massa óssea corporal podem ter igual ou maior importância na capacitação para a marcha, assim como o medo de novas fraturas ${ }^{(4,5,9)}$

Após estas constatações, pode-se concluir que o método analisado foi eficaz para prevenir fraturas e corrigir deformidades enquanto a haste se manteve no local apropriado e tinha tamanho adequado, porém o método está sujeito a complicações, principalmente graças à indistensibilidade da síntese intramedular que não acompanha o crescimento ósseo. Os tipos mais graves de Ol por sua vez, cursam com outras limitações para a marcha que não podem ser suplantadas pelo método cirúrgico aqui analisado, porém a correção da deformidade e estabilização dos seus membros inferiores, auxiliou na melhoria do seu padrão de marcha.

\section{REFERÊNCIAS BIBLIOGRÁFICAS}

1. Bailey WR, Dubow HI. Evolution of the concept of an extensible nail accommodating to normal longitudinal bone growth: clinical considerations and implications. Clin Orthop 159:157-170, 1981.

2. Bleck EE. Nonoperative treatment of osteogenesis imperfecta. Clin Orthop 159:111-122, 1981.

3. Chotigavanichaya C, Jadhav A, Bernstein RM, Watts HG. Rod diameter prediction in patients with osteogenesis imperfecta undergoing primary osteotomy. J Pediatr Orthop 21:515-518, 2001.

4. Daly K, Wisbeach A, Sanpera IJ, Fixsen JA. The prognosis for walking in osteogenesis imperfecta. J Bone Joint Surg Br 78:477-480, 1996.

5. Engelbert RH, Pruijs JE, Beemer FA, Helders PJ. Osteogenesis imperfecta in childhood: treatment strategies. Arch Phys Med Rehabil 79:1590-1594, 1998.

6. Glorieux FH, Bishop NJ, Plotkin H, Chabot G, Lanoue G, Travers R. Cyclic administration of pamidronate in children with severe osteogenesis imperfecta. N Engl J Med 339: 947-952, 1998.

7. Hoffer MM, Bullock M. The functional and social significance of orthopedic rehabilitation of mentally retarted patients with cerebral palsy. Orthop Clin North Am 12:185-191, 1981.

8. Horwitz ME, Prockop JD, Gordon PL et al. Clinical responses to bone marrow transplantation in children with severe osteogenesis imperfecta. Blood 97:12271231, 2001.

9. Khoshhal KI, Ellis RD. Effect of lower limb Sofield procedure on ambulation in osteogenesis imperfecta. J Pediatr Orthop 21:233-235, 2001.

10. King JD, Bobenchko WP. Osteogenesis imperfecta: an orthopaedic description and surgical review. J Bone Joint Surg Br 53:72-89, 1971.

11. Lang-Stevenson Al, Sharrard WJ. Intramedullary rodding with Bailey-Dubow extensible rods in osteogenesis imperfecta. J Bone Joint Surg Br 66:227-232, 1984. would be when the patient is learning to walk in order that patient's development is stimulated ${ }^{(5)}$. However, the severity of the disease must be always taken into account. Patients aged $\leq 3$ or 4 years with more severe types of $\mathrm{OI}$ can be submitted to closed osteoclasia and percutaneous intramedullary fixation so as to correct deformities and promote bone stabilization with a less invasive procedure, with no prejudice to future treatments ${ }^{(20,21)}$.

In general, the walking hability of patients with $\mathrm{Ol}$ is determined by disease severity and is adversely affected by deformities and multiple fractures requiring long periods of immobilization ${ }^{(19,22)}$.

Following surgery no patient had his/her walking hability worsened. On the contrary walking hability improved in three patients following deformity correction and skeletal stabilization of limbs. Although no patient had his/her walking hability worsened at first, some time later, two patients with type III and IV according to Sillence et al ${ }^{(1)}$ criteria became unable to walk subsequently. According to the natural course of the disease, type-III and -IV patients have a severe bone fragility and marked osteoporosis and are expected to lose their motor capabilities during the second decade of life because of vertebral column deformities, lack of motivation, and tendency to the use of wheelchair ${ }^{(1,3)}$.

Although the Sofield e Millar(10) technique allows one to correct deformities and decreases the frequency of fractures, other factors also affect walking hability of patients with OI(19). Immobilization, decreased muscular force, decreased bone mass can be equally important, as well as fear of new fractures in determining the walking hability (3,19,22).

The study findings allow one to conclude that the analyzed technique was effective in preventing fractures and correcting deformities. Rods were kept in place and was of the appropriate size. However, complications can develop mainly because intramedullary syntheses were not extensible and, therefore, did not accompany bone growth. The more severe types of OI, in turn, are accompanied by other walking-limiting factors that cannot be surpassed by the surgical technique analyzed in the present study.

However, deformity correction and lower-limb stabilization improved their walking pattern.

12. Luhmann SJ, Sheridan JJ, Capelli AM, Schoenecker PL. Management of lower-extremity deformities in osteogenesis imperfecta with extensible intramedullary rod technique: a 20-year experience. J Pediatr Orthop 18: 88-94, 1998.

13. Marafioti RL, Westin GW. Enlongating intramedullary rods in the treatment of osteogenesis imperfecta. J Bone Joint Surg Am 59:467-472, 1977.

14. McHale KA, Tenuta JJ, Tosi LL, McKay DW. Percutaneous intramedullary fixation of long bone deformity in severe osteogenesis imperfecta. Clin Orthop 305:242-248, 1994.

15. Middleton RW. Closed intramedullary rodding for osteogenesis imperfecta. J Bone Joint Surg Br 66:652-655, 1984.

16. Porat S, Heller E, Seidman DS, Meyer S. Functional results of operation in osteogenesis imperfecta: elongating and nonelongating rods. J Pediatr Orthop 11:200-203, 1991.

17. Sillence DO, Senn A, Danks DM. Genetic heterogeneity in osteogenensis imperfecta. J Med Genet 16:101-106, 1979.

18. Sillence DO. Osteogenesis imperfecta: na expanding panorama of variants. Clin Orthop 159:11-25, 1981.

19. Sofield HA, Millar EA. Fragmentation, realignment, and intramedullary rod fixation of deformities of the long bones in children. J Bone Joint Surg Am 41:1371-1391, 1959

20. Stockley I, Bell MJ, Sharrard WJ. The role of expanding intramedullary rods in osteogenesis imperfecta. J Bone Joint Surg Br 71:422-427, 1989.

21. Tachdjian MO. "Osteogenesis imperfecta" in Pediatrics orthopedics. Philadelphia, Saunders, 1990. p.780-781.

22. Tiley F, Albright JA. Osteogenesis imperfecta: treatment by multiple osteotomy and intramedullary rod insertion. J Bone Joint Surg Am 55: 701-713, 1973. 